\title{
Anterior third ventricle meningiomas. Report of two cases
}

\author{
E.R. Uygur; B. Deniz and K. Zafer
}

Ministry of Health Dışkapı Education and Research Hospital. Second Neurosurgery Clinic. Ankara. Turkey

\begin{abstract}
Summary
Third ventricle meningiomas are rare, representing approximately $0,15 \%$ of all meningiomas. The majority of third ventricular meningiomas are located posteriorly in the pineal region. Less commonly, they arise in the anterior part of the third ventricle. We report the cases of two patients with large and giant meningiomas originating in the anterior part of the third ventricle.
\end{abstract}

KEY WORDS: Meningioma. Intraventricular tumor. Third ventricle

Meningiomas del tercer ventrículo. Presentación de dos casos

\section{Resumen}

Los meningiomas del tercer ventrículo son raros. Representan, aproximadamente, el $0,15 \%$ de todos los meningiomas. La mayoría de los meningiomas del tercer ventrículo se localizan en la parte posterior, en la región pineal. Menos frecuentemente se originan en la parte anterior del tercer ventrículo. Presentamos los casos de dos pacientes con meningiomas grandes y gigantes, con origen en la parte anterior del tercer ventrículo.

PALABRAS CLAVE: Meningioma. Tumor intraventricular. Tercer ventrículo.

Meningiomas comprise $13-18 \%$ of all intracranial tumors; intraventricular meningiomas constitute $0,5-5,0 \%$ of all meningiomas ${ }^{8,19,21,22}$. The majority of intraventricular meningiomas are found in the trigone of the lateral ventricle, predominantly on the left side ${ }^{4}$. Those meningiomas arising in the third ventricle are rare, approximately $0,15 \%$ of all meningiomas ${ }^{3,6,18}$, and are usually located posteriorly in the pineal region ${ }^{6,14,17}$. Less commonly, third ventricle meningiomas arise in the anterior part of the

Recibido: 25-08-07-Aceptado: 2-10-07 third ventricle ${ }^{6,15}$. We report two cases with large and giant meningiomas originating in the anterior part of the third ventricle and discuss the differential diagnosis and treatment options of this rare tumor.

\section{Case 1}

A 25-year-old woman was admitted with a three month history of headache and almost three weeks of left sided weaknes. Neurological examination disclosed papilledema, 4/5 left hemiparesis, and left hemihypesthesia. Magnetic resonance (MR) imaging of the brain demonstrated an homogeneously enhancing midline mass within the third ventricle causing hydrocephalus (Figure $1 \mathrm{a}, \mathrm{b}$ ). The tumor, which was adherent to the anterior portion of the third ventricle, was removed near totally via an interhemispheric transcallosal approach (Figure 2 a,b). Postoperative course was uneventful. Pathological examination revealed a psammomatous meningioma.

\section{Case 2}

A 25-year-old woman was admitted with a four month history of headache and diplopia on right lateral gaze, and one week of vomiting. Neurological examination disclosed only papilledema. MR imaging of the brain demonstrated an homogeneously enhancing third ventricular mass (Figure $3 \mathrm{a}, \mathrm{b}$ ). A right sided transcortical transventricular approach to the third ventricle was performed. The tumor was near totally removed (Figure $4 \mathrm{a}, \mathrm{b}$ ). Postoperative course was uneventful. Pathological examination revealed a meningothelial meningioma.

\section{Discussion}

An heterogeneous group of lesions can be found in the third ventricle and a variety of neoplasms can occur within it. Astrocytomas, germinomas, craniopharyngiomas, chroroid plexus papillomas, teratomas, ependymomas and colloid cysts can appear in this location ${ }^{20}$. Most of these tumors are located much more frequently in the anterior 


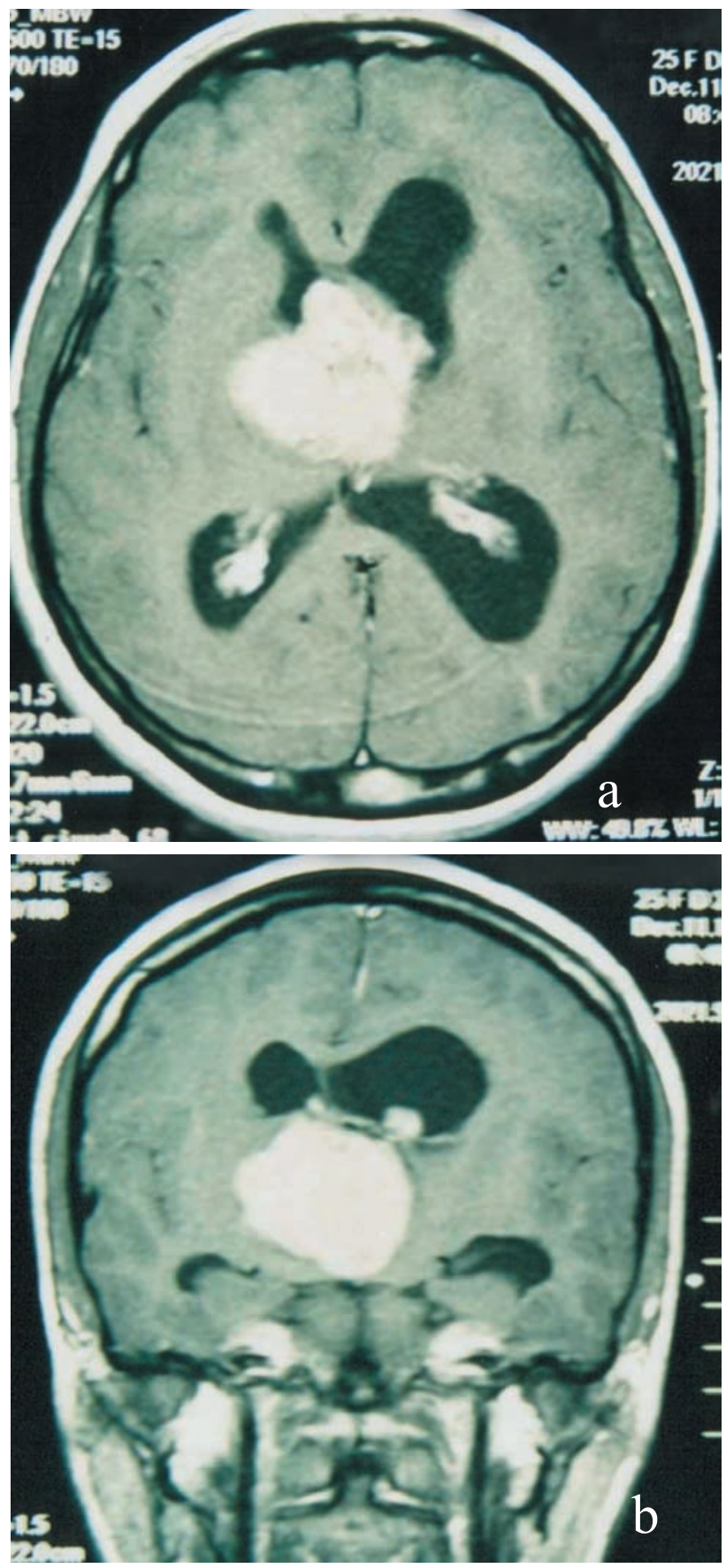

Figure 1. Preoperative axial (a) and coronal (b) T1-weighted contrast-enhanced MRI scans of case 1. The mass, filling the IIIrd ventricle, is well demarcated and shows solid, homogeneous enhancement.

part of the third ventricle compared with the posterior $\operatorname{part}^{20}$. However, meningiomas are more commonly found posteriorly $y^{6,9,14,17,18}$. Tumor location, age of the patient and imaging characteristics can help the differential diagno$\operatorname{sis}^{20}$.
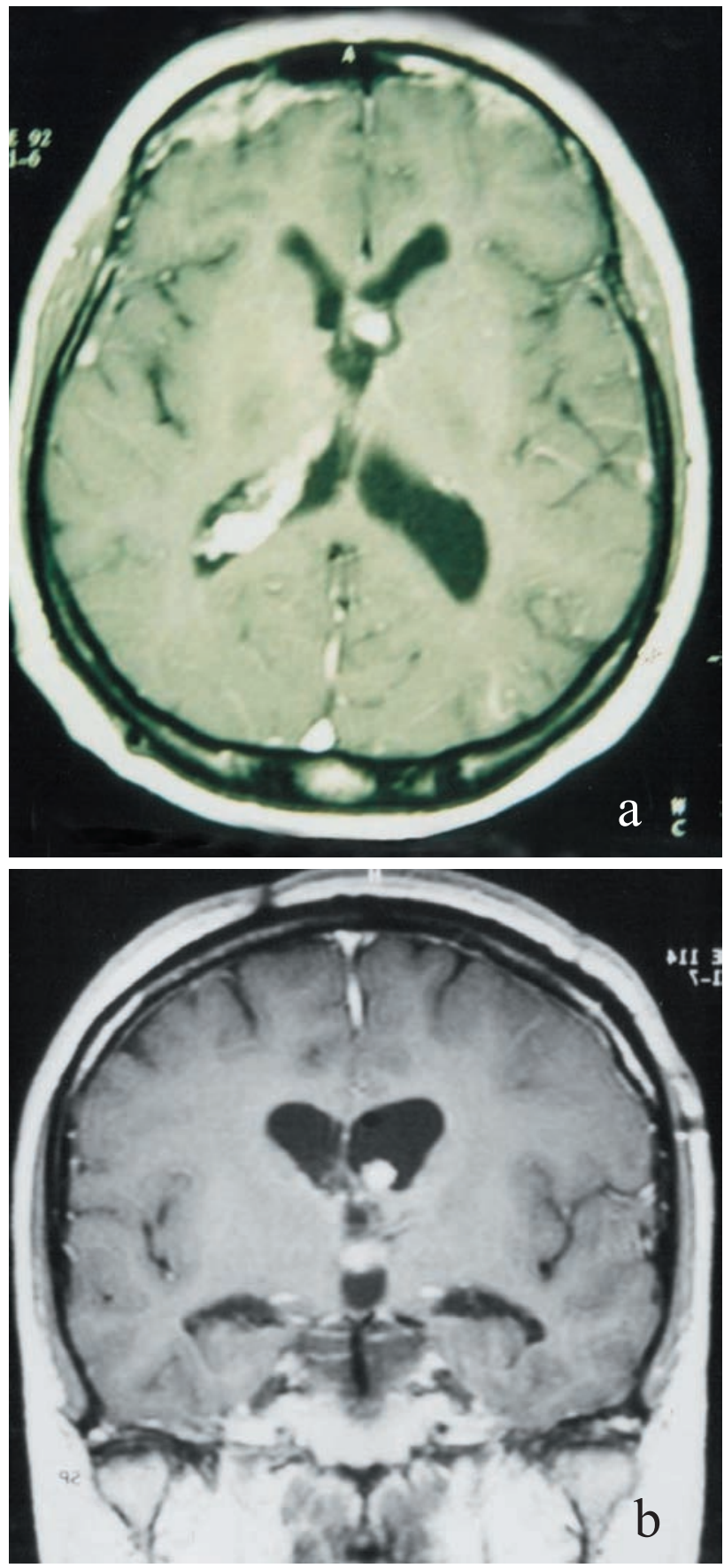

Figure 2. Postoperative axial (a) and coronal (b) T1-weighted contrast-enhanced MRI scans of case 1. Approximately $8 \times 6 \mathrm{~mm}$ of residual contrast-enhancement is seen.

Third ventricle meningiomas arise from the stroma of the choroid plexus or from the tela choroidea which together constitute the membrana tectoria ${ }^{3,8,14,17,18}$. The presence of arachnoid cell nests in the normal choroid plexus stroma has been illustrated in the literature and a thorough examination of the choroid plexus usually reveals small 

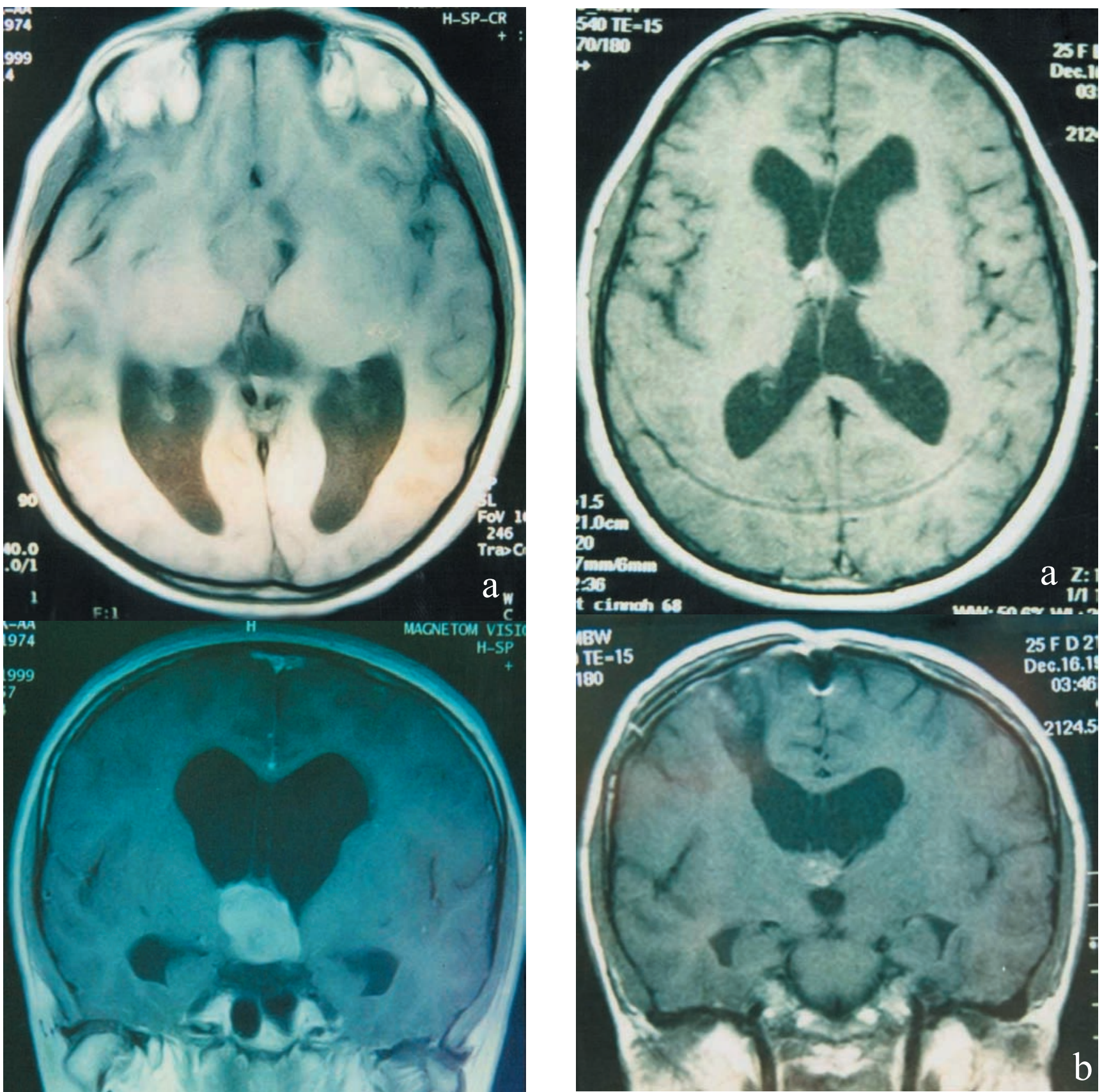

Figure 4. Postoperative contrast-enhanced axial (a) and coronal (b) T1-weighted MRI of case 2. A $6 \times 6 \mathrm{~mm}$. minimally enhanced residual lesion is seen.

Figure 3. Preoperative unenhanced axial (a) and contrastenhanced coronal (b) T1-weighted MRI scans of case 2. Well demarcated, 2,5x3x3 $\mathrm{cm}$. mass in the IIIrd ventricle is seen. The mass enhanced intensely after gadolinium administration.

or sometimes larger collections of these cells $\mathrm{s}^{4}$. In the $7^{\text {th }}$ to $9^{\text {th }}$ gestational weeks, the telencephalic choroid plexus has started to develop a loose mesenchymal stroma, which is covered by a layer of cells derived from the ependyma.

Arachnoid tissue is transported together with the choroid plexus as the ventricular system invaginates, and by 20 to 40 weeks, the central stroma of the choroid plexus contains meningocytes, connective tissue, and blood vessels. In a similar fashion, intraventricular meningiomas arise from arachnoid cells contained within the choroid plexus. Meningothelial inclusion bodies are normally found in the arachnoid and choroidal tela, and meningiomas arise from 
this mesenchymal stroma of the choroid plexus ${ }^{4}$. These tumors receive their blood supply from the medial posterior choroidal arteries ${ }^{8,14}$. Third ventricle meningiomas which constitute $0.15 \%$ of all meningiomas ${ }^{3,6,18}$ are more frequent in children and adolescents ${ }^{8,16}$. In general, intraventricular meningiomas predominate in females, but third ventricular meningiomas are more common in males $3,4,8,9,14,22$. They have been encountered in patients between 3-53 years of age, with a peak incidence in the second decade ${ }^{3,8}$. In von Recklinghausen's disease the incidence of intraventricular meningiomas is $16.6 \%$ and several cases of meningioma of the third ventricle are reported ${ }^{3,4,15}$. The majority of the third ventricle meningiomas are fibroblastic, syncytial or of mixed type $e^{3,69,10,11}$. An atypical meningioma in a 6-yearold boy ${ }^{12}$, a transitional meningioma in a 5-year-old gir $^{17}$, a psammomatous meningioma in a 7-year-old boy $^{3}$ and a malignant meningioma in a 61 -year-old woman ${ }^{19}$ are reported in the literature.

Third ventricular meningiomas commonly present with signs and symptoms of increased intracranial pressure from hydrocephalus without any localizing neurological $\operatorname{sign}^{1,3,4,6,8,17,18}$. Posterior third ventricular meningiomas present as pineal masses with Parinaud's syndrome ${ }^{3,17,18}$. A case of anterior third ventricle meningioma without signs or symptoms of increased intracranial pressure is also reported $^{5}$. Headache, vomiting, visual disturbances, ataxia, tremor, Parkinson like syndrome, endocrine abnormalities ${ }^{1}$, epilepsy, akinesia, poliuria, polidypsia and narcoleptic seizures are reported with anterior third ventricle meningio$\operatorname{mas}^{3,12,17,18,22}$.

Third ventricle meningiomas are hyperdense lesions on computerized tomography (CT). MR imaging usually demonstrates an hypointense to isointense lesion on T1, and isointense to hyperintense lesion on T2-weighted images. Typically, these neoplasms brightly enhance with contrast administration on CT or MRI ${ }^{17,20}$.

Total removal of third ventricle meningiomas can be achieved through interhemispheric transcallosal or transcortical transventricular approaches ${ }^{3,4,6,17,18,19,22}$. Transcortical transventricular approach requires cortical incision to reach the lateral ventricle. This approach is best used for lesions with a significant intravenricular component within the third ventricle and associated enlarged lateral ventricles. The most frequent complication of this approach is the occurrence of postoperative seizures in a frequency that has been reported to be as high as $27 \%^{2}$, presumably as a result of the cortical incision which creates an epileptogenic focus. Neurological deficits and memory loss have also been reported following transcortical transventricular approach to the anterior third ventricle ${ }^{2}$. Finally, if the lateral ventricles are large, drainage of the ventricles through the cortical incision can lead to cortical collapse and subdural fluid collections.
The interhemispheric transcallosal approach permits to enter the third ventricle without a cortical incision. Ventriculomegaly is not a prerequisite for this approach. Hemiparesis, mental status changes, memory disturbances, confusion and mutism have been reported following this approach $^{2}$. Posterior transcallosal approach may be used for posterior third ventricular meningiomas without any major complication ${ }^{13,21}$. In our view, transcallosal approach seems less traumatic and more straightforward independently of the surgeon's habit.

\section{Conclusion}

Two cases of large meningiomas of the anterior third ventricle, which were succesfully surgically removed, are presented. Although its incidence is rare, a confined round mass in the third ventricle revealed by CT or MRI, should raise the suspicion of meningioma as one of the possible diagnoses.

\section{References}

1. Albert, P.: Tumors and other space occupying lesions of the anterior part of the third ventricle. Neurocirugía 1999; 10: 27-41

2. Apuzzo, M.L.J., Litofsky, N.S.: Surgery in and around the Anterior Third Ventricle. In: Apuzzo MLJ (ed), Brain Surgery, vol 1, New York: Churchill Livingstone, 1993. pp. 541579.

3. Avman, N., Dinçer, C.: Meningiomas of the third ventricle. Acta Neurochir 1978;42: 217-224.

4. Bhatoe, H.S., Singh, P., Dutta, V.: Intraventricular meningiomas: a clinicopathological study and review of the literature. Neurosurg Focus 2006; 20(3): E9

5. Cabeduzo, J.M., Vaquero, J., García-de-Sola, R., Areitio, E., Bravo, G.: Meningioma of the anterior part of the third ventricle. Acta Neurochir (Wien) 1981;56: 219-231.

6. Castillo, R.G., Geise, A.W.: Meningioma of the third ventricle. Surg Neurol 1985; 24: 525-528.

7. Costa, L.B., Vilela, M.D., Lemos, S.: Third ventricle meningioma in a child: case report. Arq Neuropsiquiatr 2000; 58: 931-934.

8. Dağçınar, A., Elmacı, İ., Özgen, S., Bayri, Y., Özek, M.M., Pamir, M.N.: İntraventriküler meningiomlar. Türk Nöroşir Derg 2000; 10: 144-150.

9. Dinc, C., Iplikçioglu, A.C., Cakabay, M., Tufan, A., Kosdere, S.: Third ventricle meningioma Journal of Neurological Sciences (Turkish) 2005; 22: 089-093.

10. Gabriel, I.: Meningioma of the anterior part of the third ventricle. Clinical case. Neurochirurgie 1995; 41: 120-123.

11. Gelabert, G.M., Fernández, F.M.A., Bollar, Z.A., García, A.A., Martínez, R.R.: Meningioma of the third ventricle. Presentation of a case. Arch Neurobiol (Madrid) 1989; 52: 
100-104.

12. Huang, P.P., Doyle, W.K., Abbott, I.R.: Atypical meningioma of the third ventricle in a 6-year-old boy. Neurosurgery $1993 ; 33: 312-315$.

13. Kasowski, H., Piepmeier, J.: Transcallosal approach for tumors of the lateral and third ventricles. Neurosurg Focus June 2001;10: 1-5.

14. Markwalder, T.M., Markwalder, R.V., Markwalder, H.M.: Meningioma of the anterior part of the third ventricle. J Neurosurg 1979; 50: 233-235.

15. Pandya, P., Cyhisti, K., Bannister, C.M.: A third ventricular meningioma in a child. Br J Neurosurg 1990; 4: 129-133.

16. Pau, A., Dorcaratto, A., Pisani, R.: Third ventricular meningiomas of infancy. A case report. Pathologica 1996; 88: 204-206.

17. Renfro, M., Delashaw, J.B., Peters, K., Rhoton, M.D.: Anterior third ventricle meningioma in an adolescent: A case report. Neurosurgery 1992; 31: 746-750.

18. Sayette, V., Rivaton, F., Chapon, F., Hubert, P., Ganem, F., Houtteville, J.P.: Meningioma of the third ventricle. Neuro- radiology 1991; 33: 354-356.

19. Strenger, S.W., Huang, Y.P., Sachdev, V.P.: Malignant meningioma within the third ventricle: A case report. Neurosurgery 1987; 20: 465-468.

20. Suh, D.Y., Mapstone, T.: Pediatric supratentorial intraventricular tumors. Neurosurg Focus June 2001; 10: 6-14.

21. Tahsin, E., Gocer, A.I., Seyda, E., Boyar, B, Haciyakupoglu, S., Zorludemir, S.: Intraventricular Meningiomas: A review of the literature and report of 8 cases. Neurosurgery Quarterly Sep 2004; 14: 154-160.

22. Wakai, S., Nakamura, K., Niizaki, K., Nagai, M., Nishizawa, T., Yokoyama, S., Kalayama, G.: Meningioma of the anterior third ventricle presenting with parkinsonizm. Surg Neurol 1984; 21: 88-92.

Uygur, E.R.; Deniz, B.; Zafer, K.: Anterior third ventricle meningiomas. Report of two cases. Neurocirugía 2008; 19 : 356-360.

Corresponding author: Uygur ER. Sogütözü Caddesi, 4. Sokak, No: 22/7, 06510, Ankara, Turkey. 